\title{
Capital account regulation in Brazil: An assessment of the 2009-2013 period $^{1 "}$
}

\author{
Regulação dos fluxos de capitais no Brasil: \\ Uma avaliação do período 2009-2013
}

DANIELA MAGALHÃES PRATES

LUIZ FERNANDO DE PAULA*

RESUMO: O Brasil foi um dos países emergentes que enfrentou fortes pressões de apreciação cambial entre o $2^{\circ}$ trimestre de 2009 e julho de 2011. É sob este contexto que pode ser entendida a aplicação da Regulação da Conta Capital (CAR) depois de 2009, que foi complementada com outro tipo de regulação, a Regulação dos Derivativos Cambiais (FXDR). Este trabalho mostra que, somente quando o governo brasileiro adotou estes dois tipos de regulação simultaneamente, houve um aumento da eficácia das políticas em deter essas pressões. A experiência brasileira também revela que não é possível estabelecer uma hierarquia entre os instrumentos temporários para gerenciar fluxos de capital e medidas prudenciais permanentes, tal como defende a abordagem atual do FMI.

PALAVRAS-CHAVE: liberalização da conta de capital; controles de capitais; economia brasileira.

ABSTRACT: Brazil was one of the emerging countries that had a stronger trend of currency appreciation from the 2 nd quarter of 2009 to July 2011. Under this context that can be understood the implementation of capital account regulation (CAR) after 2009, which was complemented with another kind of regulation, the so-called FX Derivatives Regulation (FXDR). This paper shows that only when Brazilian government adopted these two kinds of regulations simultaneously, the policy effectiveness increased in terms of protecting the Brazilian currency from upward pressures. Brazilian experience also highlights that it is not possible to establish a hierarchy between temporary instruments to manage capital flows and permanent prudential measures, as supported by the IMF current approach. KEYWORDS: capital account liberalization; capital controls; Brazilian economy. JEL classification: F31; F32; F53.

\footnotetext{
$1^{*}$ We are grateful for the research assistance of Aline Gomes and the comments of the anonymous referee. All remaining errors are the authors' responsibility.

* Professor of Economics da Universidade Estadual de Campinas (UNICAMP) and CNPq researcher. Email: prates@unicamp.br; Professor of Economics da Universidade do Estado do Rio de Janeiro (UERJ) and CNPq researcher. Email: luizfpaula@terra.com.br. Submitted: 6/August/2015; Approved: 15/ $\mathrm{March} / 2016$.
} 


\section{INTRODUCTION}

A new wave of capital flows to emerging economies, boosted by the post-crisis circumstances (quantitative easing policies and historical low interest rates in advanced countries, etc.), took place from the 2nd quarter of 2009 to the first quarter of 2013. In May 2013, when the Federal Reserve (Fed) merely indicated that it might begin tapering this policy toward the end of the calendar year, global investors set into motion a portfolio adjustment that caused a temporary but significant reversal in capital flows to U.S., putting upward pressures on the exchange rates of many emerging economies (BIS, 2014).

During the boom phase of the recent cycle, once more, "emerging-market assets" became objects of desire on the part of global investors, resuming policy dilemmas to emerging countries stemming from the combination of high growth rates, accelerating inflation (associated with the post-crisis commodity prices boom), excessive currency appreciation and/or asset price overshooting.

In order to deal with these policy dilemmas, some of these countries resorted to capital account regulation (CAR), which encompasses capital controls and financial prudential regulation (Gallagher et al, 2012). This regulation aimed at halting the trend of currency appreciation and of speculative bubbles in asset prices as well as at reducing the risks of rising current account deficits and the costs of excessive Foreign Exchange (FX) reserve accumulation. Thus, unlike the pre-crisis context, most of these countries did not adopt a hands-off approach to capital inflows.

Brazil was one of the emerging countries that had a stronger trend of currency appreciation until July 2011 due to the combination of huge capital inflows, increasing commodity prices, high domestic interest rate, and a sophisticated and deep FX derivatives market completely open to foreign investors that provides room for speculation on the exchange rate through operations with FX derivatives (the so-called derivatives carry-trade). Under this context that can be understood the recent implementation of the CAR, which was complemented with another kind of regulation, called here FX Derivatives Regulation (FXDR), whose target is FX derivatives operations of all agents, being them financial and non-financial as well as non-residents and residents.

As the experience of implementation of capital account regulation (CAR) in 2009-2013 in Brazil is still recent there are few empirical works that assessed its effectiveness. Using a GARCH regression, Baumann and Gallagher (2012) found that the introduction of CAR in Brazil between October 2009 and December 2012 had a small but significant impact on shifting the composition of capital inflows toward longer-term investment, on curbing the level and volatility of exchange rate, and on modestly increasing Brazilian monetary policy autonomy. Another empirical study (Chamon and Garcia, 2016) analyzed the impact of the capital controls adopted in Brazil from late 2009 until 2012, and concluded that while 
the first several measures (until mid-2011) had very limited success in containing the currency appreciation, the Brazilian exchange rate seems to respond strongly just after the adoption of a financial tax on the notional amount of derivatives. On the other hand, Klein (2012), by analyzing the pattern of controls on capital inflows in a set of 44 advanced and emerging economies (including Brazil), concluded that the Brazilian tax on financial operations (IOF) was an episodic control on the capital inflows that did not temper the appreciation of the Brazilian currency; however, the period covered in his study ended in 2010, therefore before the adoption of a broader FXDR.

Differently from these empirical assessments based on econometric methods, this paper applies qualitative methods and descriptive statistics to analyze the measures of CAR and FXDR implemented in Brazil over 2009-2013. This approach was chosen due to the overlap and interdependency of factors affecting the Brazilian exchange rate path in this period: i) external shocks with high frequency, given the unstable global environment and the even high volatility of international capital flows after the global financial crisis; ii) macroeconomic policy shifts, especially in monetary and foreign exchange policies; iii) frequent changes in regulation at the domestic level.

In line with the empirical findings of Baumann and Gallagher (2012) and Chamon and Garcia (2016), our assessment suggest that the regulations adopted in Brazil in the aforementioned period were effective in affecting the exchange rate path, yet only when the three kinds of measures (capital controls, prudential financial regulation and FXDR) were simultaneously in place the policy effectiveness increased in terms of protecting the Brazilian currency from upward pressures. Therefore, our main contribution is to show that there are important feedbacks between capital controls, prudential financial regulation and FXDR, as much as between these measures and macroeconomic policy, so that it is not possible to establish a hierarchy between instruments to manage capital flows and curb their undesirable outcomes (such as currency appreciation and financial fragility) as supported by the current IMF approach.

The arguments are organized in four sections, besides this introduction. Second section focuses on international financial integration, capital flows and CAR in emerging economies, including a brief discussion on the new institutional view of the International Monetary Fund (IMF) on capital controls. Third section provides a brief overview of capital flows and capital account liberalization in Brazil. Fourth section details the specificity of the Brazilian experience and the key features of CAR and FXDR after the global financial crisis. Some lessons from the Brazilian experience are presented in the final section. 


\section{INTERNATIONAL FINANCIAL INTEGRATION, CAPITAL FLOWS AND CAPITAL ACCOUNT REGULATION IN EMERGING ECONOMIES}

\section{International financial integration, economic performance and macroeconomic instability}

Prasad et al. (2003) sum up the conventional view that gives support to international financial integration, pointing out that the potential benefits of financial liberalization for emerging market countries can be divided in two channels: direct and indirect. Direct channels include augmentation of domestic savings ${ }^{2}$, reduction in the cost of capital due to better global allocation of risk, reduction of consumption volatility, transfer of technological and managerial know-how, and stimulation of domestic financial sector development. Indirect channels include promotion of specialization, commitment to better economic policies, and signaling the practice of more friendly policies. Therefore, according to this view financial liberalization results in market discipline that shall stimulate more consistent macroeconomic policy (understood as sound fiscal and monetary policies, etc.) as market force ("rational foreign investors") can penalize bad policies.

A lot of empirical works, most of them using panel data and measuring the international financial integration with the use of different de jure and de facto indexes, seek to evaluate the relationship between capital account liberalization, on one hand, and economic growth, financial crises and/or macroeconomic volatility, on the other hand. Some surveys conclude that empirical evidences in general do not present a robust relationship between financial liberalization and economic growth (Prasad et al., 2003; Einchengreen, 2004, Ch 3).

Some IMF's economists works have acknowledged the potential risks and costs related to international financial integration and specifically to the volatility of capital flows in emerging economies (Prasad et al., 2003; Kose et al., 2006; IMF, 2008), as the surge of capital inflows can have negative effects on emerging economies, including the appreciation of the domestic currency beyond the equilibrium level, fiscal costs of sterilization related to international reserves accumulation, inflationary pressures can result from incomplete sterilization and/or credit boom, and possible bubbles in certain sectors as equity markets. However, IMF (2008) sustains that financial globalization leads to better macroeconomic outcomes when certain threshold conditions of financial and institutional developments are met (financial market development, institutional quality, sound macroeconomic policies, trade integration), but some analysts have argued that such conditions are almost the same factors pointed out as collateral benefits of financial globalization, generating a logical contradiction between consequences and causes (Biancareli, 2008).

Yet, since the breakdown of the Bretton Woods system, some prominent mainstream economists have stressed that with the financial liberalization and the

\footnotetext{
${ }^{2}$ This augmentation is related to the notion that capital flows from capital-rich countries to the capitalpoor countries due to a comparatively higher marginal productivity capital in the former ones.
} 
emergence and spread of new financial instruments (such as derivatives), the likelihood of occurrence of speculative financial operations increases substantially. Tobin (1978) was one of the first economists to state that the main macroeconomic problem related to integrated financial markets is not the choice of the appropriate exchange rate regime but the excessive short-run capital mobility that reduces the autonomy of national governments to pursue domestic objectives with respect to employment, output and inflation. Stepping forward Stiglitz (2000) points out that capital flows to emerging countries are markedly pro-cyclical and exacerbate economic booms, and that financial liberalization exposes countries to the vicissitudes associated with changes in economic circumstances outside the country; so that such economies are exposed to sudden change in lenders' and investors' perceptions.

As the Post Keynesian literature (Schulmeister, 1988; Harvey, 2009) highlighted, in this setting, featured by floating exchange rates and free capital mobility, short-term capital flows constitute the chief determinant of nominal exchange rates, which are highly volatile. In this perspective, the speculative feature of these flows, subordinate to financial investors' risk aversion/appetite, is the main cause of the volatility of exchange rates. However, exchange rate volatility in general is higher in emerging economies than in developed ones due to the monetary asymmetry of the international monetary and financial system that refers to the hierarchical dimension of the international monetary system. In other words, national currencies are hierarchically positioned according to their degree of liquidity, which relates to their ability to perform internationally the three functions of money: medium of exchange, unit of account and denomination of contracts, and store of value (international reserve currency). The key currency (currently, the fiduciary US dollar) is placed at the top of the hierarchy because it has the highest degree of liquidity. The currencies issued by the other core countries are in intermediate position, as they have a high liquidity premium, but not as high as the dollar. At the opposite end are the currencies issued by the emerging economies, which are nonliquid currencies, for they are incapable of performing those functions. Consequently, these currencies, priced with a lower liquidity premium, are especially vulnerable to the inherent volatility of capital flows in the post-Bretton Woods system. The smaller and less liquid foreign exchange and financial markets of emerging economies make them more vulnerable to one-way expectations and herd behavior (Andrade and Prates, 2013).

\section{Policy space and capital account regulation}

In order to enhance the possibility of a successful management of exchange rate regime in emerging economies some measures to reduce the volatility of capital flows and the likelihood of speculation attack against the domestic currency can be necessary. One possibility is the use of official intervention in the foreign exchange market, which may exert direct influence on nominal exchange rate as it alters the relative supply of domestic and foreign currencies. On the one hand, 
the countries' ability to resist currency depreciation is limited by its stock of foreign exchange reserves and its access to potential credit lines. Thus, reserve accumulation can be seen as an insurance against future negative shocks and speculation against the domestic currency, as emerging economies have limited access to the international capital market during times of high risk aversion of foreign investors. On the other hand, the ability to avoid currency appreciation may require the use of sterilized intervention. Monetary authorities have often sought to sterilize the impact of foreign exchange intervention through open market operations and other measures, such as increasing bank reserve requirements. Moreover, sterilization often implies quasi-fiscal costs, as it in general involves the central bank exchanging high-yield domestic assets for low-yield foreign reserves (Cardarelli et al., 2009).

Another possibility to enhance the management of the exchange rate regime (that is not excluding official intervention in the currency markets) in emerging economies is the use of 'capital account regulation' (CAR) (Gallagher et al., 2012) or 'capital management techniques' which include capital controls, that is measures that manage volume, composition, and/or allocation of international private capital flows, and/or 'prudential domestic financial regulations', which refer to policies, such as capital-adequacy standards, reporting requirements, or restrictions on the ability and terms under which domestic financial institutions can provide to certain types of projects (Epstein et al., 2003: p.6-7). Capital controls can be used for different though related objectives, such as: (i) to reduce the vulnerability of a country to financial crises, including capital flight during currency crisis; (ii) to drive a wedge between onshore and offshore interest rates in order to provide monetary authorities with some policy autonomy at least in the short-run; and (iii) to maintain some short-term stability of nominal exchange rate and to reduce exchange rate pressures derived from excessive capital inflows.

Regarding the effectiveness of CAR, Magud and Reinhart (2006) review more than 30 papers that evaluated capital controls either on inflows or outflows around the world, making use of a capital controls effectiveness index in order to standardize the results of the empirical studies. They conclude that "capital controls on inflows seem to make monetary policy more independent; alter the composition of capital flow; reduce real exchange rate pressures (although the evidence is more controversial)", but "seem not to reduce the volume of net flows (and hence, the current account balance)", while "limiting private external borrowing in the 'good times' plays an important prudential role because more often than not countries that are 'debt intolerant'" (Magud and Reinhart, 2006: 26-27). Finally, Magud and Reinhart (2006) argue that enhancing the effectiveness of capital controls is necessary to take into account country-specific characteristics in their design.

Concerned with the amount and volatility of capital flows to emerging economies after the contagious of the 2008 crisis, IMF revised its official position regarding the evaluation of capital controls (IMF, 2010, 2011, 2012b; Ostry et al. 
2010, 2011). This finally resulted in a new institutional view endorsed by the IMF (IMF, 2012), especially with regards to the regulation of capital inflows.

In fact, the IMF in its definitive policy framework (IMF 2012) has made relevant progress compared not only to its traditional rejection of capital controls but also in comparison to its preliminary approaches of 2010 and 2011 to tolerate capital controls under highly specific circumstances (Ostry et al. 2010 to IMF, 2011). By introducing the new term "capital flow management measures" (CFMs), IMF gives more policy space to emerging economies subject to major capital inflow surges inasmuch it loosened the clear-cut hierarchy between instruments to manage capital flows which cover the whole range of macroeconomic policies, prudential regulations and capital controls (defined in a jurisdictional manner).

Yet, at the same time, this new policy framework contains two main shortcomings. First, by defining CFMs as a temporary instrument embedded in an overall strategy of financial opening, the organization insists on the general advantages of financial liberalization, which set serious limits to developing and emerging economies' policy space. Second, the Fund keeps defending the separation of a permanent prudential financial regulation (referred to as MPMs) and only temporary CFMs. In our view, this discrimination is not feasible especially in emerging and developing economies inasmuch their currencies are characterized by a limited acceptance at the international level which increases the potential harmful effects of international capital flows in terms of financial fragility and macroeconomic management. ${ }^{3}$

\section{CAPITAL FLOWS AND CAPITAL ACCOUNT LIBERALIZATION IN BRAZIL: A BRIEF OVERVIEW}

Capital account liberalization in Brazil began in the 1990s and was most time incremental, marked by key rules that, given their strong impact on capital inflows and outflows, can be considered as landmarks. This was the case with the approval, in 1991, of Annex IV of Central Bank of Brazil Resolution no. 1,289, permitting foreign institutional investors to participate directly in the Brazilian capital market and, in 1992, the redesign of CC5 accounts, permitting residents and non-residents to make capital transfers abroad from Brazil. So, both capital inflows and capital outflows were liberalized in Brazil. The process of financial opening gained momentum in January 2000, when the Resolution CMN no. 2,689 allowed the unrestricted access of non-resident (i.e. foreign) investors to all the segments of the domestic financial market, including the derivatives market. Afterwards, during the 2000s there was in course a process of consolidation of the foreign exchange rules (Paula, 2011).

\footnotetext{
${ }^{3}$ For a more details on the new IMF institutional view on capital controls, see Gallagher (2012) and Fritz and Prates (2014).
} 
Domestic norms on foreign exchange transactions allow the implementation of capital controls at any time - there is no formal restriction on this concern. Law 4,321/1961, which allows the adoption of controls on capital outflows by foreign investors and transnational enterprises, has not been repealed. However, there are some limits to the efficacy of CCR due to two specificities of the Brazilian economy.

The first one is the high degree of financial openness of the Brazilian economy. The country had a broad and deep experience of external financial liberalization. Although Brazil adopted a more gradual style of Washington Consensus policies compared other Latin American countries, capital account liberalization was relatively fast and widespread. The second specificity is the huge differential between internal and external interest rates, which attracted dramatically capital inflows, mainly portfolio ones, and stimulated private agents to find loopholes to circumvent the regulations (regulatory arbitrage), as detailed in the next section. Despite the reduction of the policy rate (Selic) by the BCB from August 2011 to February 2012, the differential between the internal and external interest rates has been still high compared to other emerging countries (see Figure 1). Since middle of 2013, when BCB began to increase the Selic rate seeking to reduce the inflation rate, interest rate differential increased dramatically from $5.9 \%$ to $7.8 \%$ in December 2013.

Figure 1: Interest rate differential (\%), 2010-2013

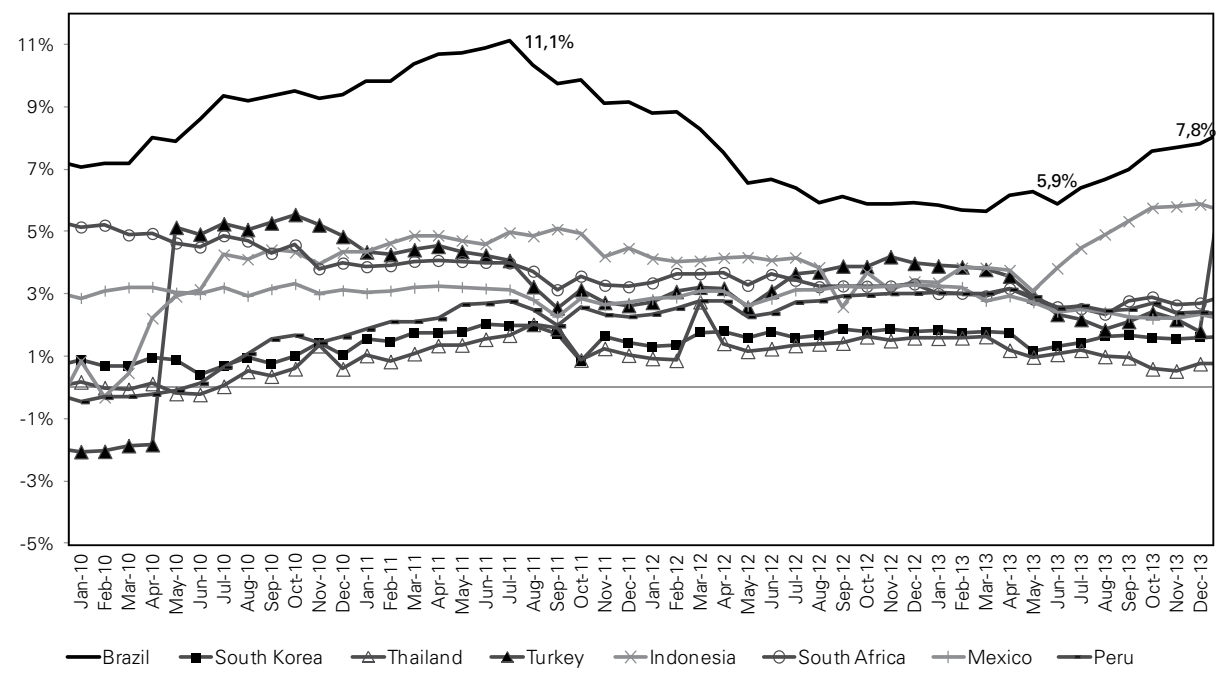

Note: (1) Interest rate differencial = Country policy rate minus Fed Fund Rate plus country-risk.

Source: Authors' elaboration with data from Central Bank of Brazil.

As we can see in the Figure 2, a new surge of capital inflows to Latin America except to Argentina and Venezuela - started in the middle of 2009, with a quick re- 
covery of capital inflows after the contagious of the global financial crisis ${ }^{4}$. The main drivers behind of this wave to emerging economies were: (i) loosening monetary policy in advanced economies due to the "quantitative easing" policy of the FED, and later of the ECB, widening the interest rate differentials and creating abundant global market liquidity; (ii) better economic performance of the emerging economies and the slow recovery of the developed countries; (iii) sound fiscal and debt position of the emerging economies relative to advance economies; and (iv) and particularly important to Latin American countries, quick and continuous recovered of commodity prices until May 2011, when prices started a decline trend. This new surge of capital inflows, however, has lost momentum (though, not sharply) and become more volatile since 2013. As we have already mentioned, in May 2013 Fed announced a gradual reduction in the monetary stimulus which resulted in a greater turbulence in the world financial market, with particular impact on emerging economies.

Figure 2: Financial account net balance (USD million), 1994-01/2014-01

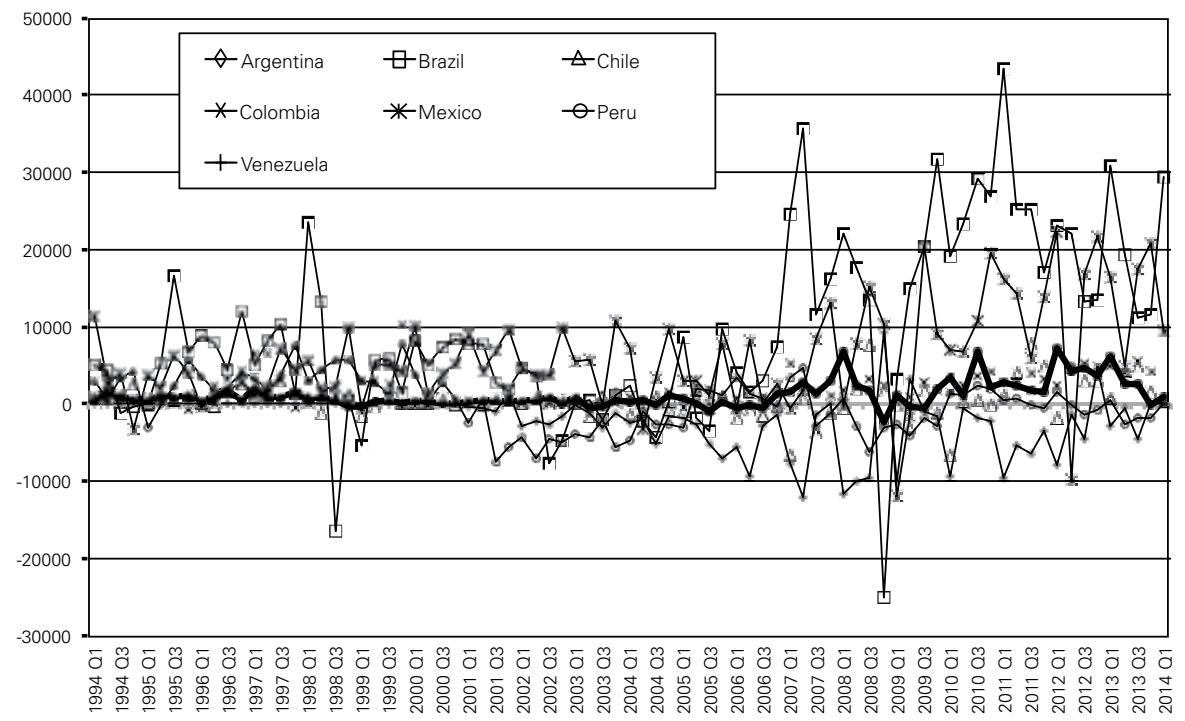

Source: MF (2014) - International Financial Statistics.

All these factors, along with improved global risk appetite, attracted capital inflows, especially portfolio debt capital flows. The episode of capital inflows after the Lehman Brother's contagion was characterized by a predominance of volatile portfolio inflows, much more than previous wave, with a sharp and unprecedented increase in the flows (net flows of more than USD 50 billion in some quarters), followed by the direct investments that have increased in 2011. Note that Brazil

\footnotetext{
${ }^{4}$ For an analysis of the causes and consequences of the capital inflows boom to Latin America in 20092011, see Paula (2013).
} 
had records of capital flows in the recent wave, followed far above by Mexico, Colombia, Peru and Chile. This movement can be attributed to the improvement in the country-risk (Brazil got the degree of "investment grade" in the second quarter of 2008) and the interest rate huge differentials.

Figure 3 shows the BCB interventions in the foreign exchange market (spot market) since 1999, when Brazil adopted a floating exchange rate regime, where negative values means that it is selling foreign currencies and positive values means that it is buying them. A general outlook shows broadly speaking two distinguish BCB pattern of intervention: (i) from 1999 to September 2005 exchange rate policy was of "free float" type, in which BCB did only eventual and few interventions, mainly in periods of instability in the foreign exchange market (such as during the 2002 confidence crisis), selling dollars in order to avoid further devaluation of the domestic currency; (ii) since October 2005 BCB began to buy foreign currencies in a continuous but uneven way, mainly as part of the international reserves accumulation policy, without having any commitment with a certain level of exchange rate, that continued to have an appreciation trend. Some more aggressive intervention was done eventually in order to reduce greater exchange rate volatility in the sense of appreciation or depreciation. So, there was a more typical dirty floating behavior. In the end of August 2013, however, BCB launched a program of selling US\$ 2 billion of FX swaps weekly, besides loans of US\$ 1 billion to the banks in the spot market every week, to smoothen the capital flight due to the announcement of the 'tapering' by Fed. As a result of such policy, BCB sold USD in the second semester of 2013 (see Figure 3).

Figure 3: BCB intervention in the foreign exchange market (US\$ billion), $1994-2013$

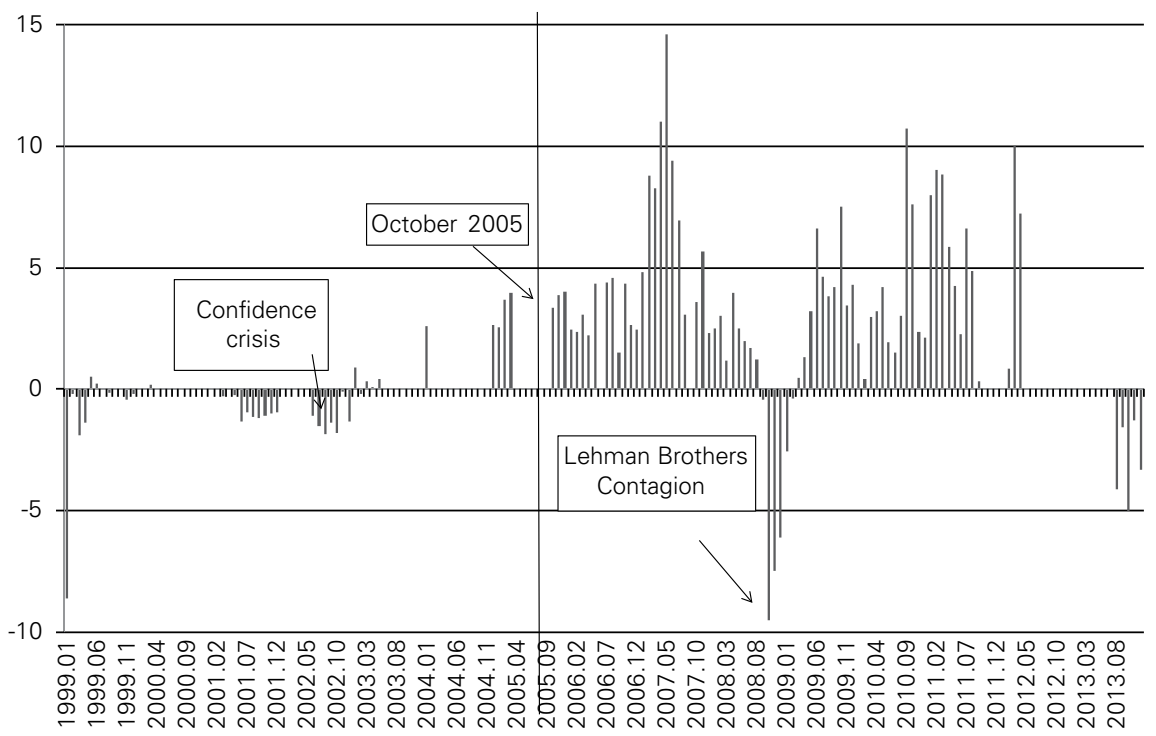

Source: Authors' elaboration with data from Central Bank of Brazil.

Note: (+) purchase (-) selling 
Since the 1990s, CCR have been mainly endogenous in Brazil, in the sense that they have been adopted and tightened during periods of boom of capital flows, and have been loosened during periods of capital flight (Cardoso and Goldfajn, 1998; Paula, 2011). The exception occurred during Lula da Silva's government when the Brazilian economy faced a capital flows boom in 20052008 without adopting CCR (instead BCB accumulated FX reserves with very high fiscal costs). During the 2000s financial liberalization was integral part of the 'model' of economic policy inspired in the New Consensus on Macroeconomics (floating exchange regime, inflation target regime and primary fiscal surplus). Likely the only important change was the policy of foreign exchange reserves accumulation that aimed at having a cushion of safety against currency speculation and reducing exchange rate volatility. It is worth to mention that Brazil compared to other major Latin American economies did a more aggressive FX reserve accumulation policy (see Figure 4), that however did not avoid the general trend for exchange rate appreciation. This trend was somehow tolerated by $\mathrm{BCB}$ as essential to the attainment of the inflation target in Brazil (Arestis et al., 2010).

Figure 4: Foreign exchange reserves (US\$ billion), 2000-2013

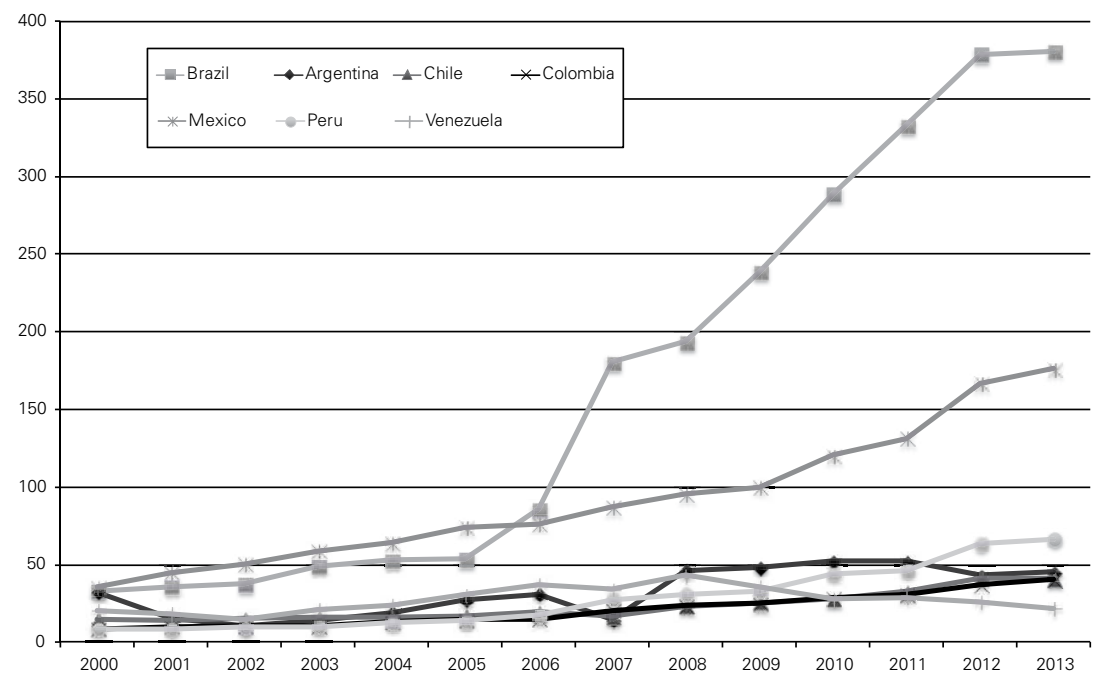

Source: IMF (2014)

Indeed, intervention in the currency markets, including accumulation of FX reserves, has been massive in Argentina, Brazil and Chile and very high in Colombia and Peru (Figure 4). However, for some economies there was a gradual trend of real appreciation of the domestic currencies due to massive capital inflows. This was the case of Brazil and Colombia that, together with Venezuela, are the countries whose currencies had a strong upward pressure in real terms, which means a downward trend of the real effective exchange rate (as the ex- 
change rate is the price of the USD) (Figure 5). Brazil was one of the emerging countries that had a stronger trend of currency appreciation until February 2012. In 2012-2013 there was some trend of currency depreciation in the major Latin American economies.

Figure 5: Real Effective Exchange Rate, 2002-2013 (2005 = 100)

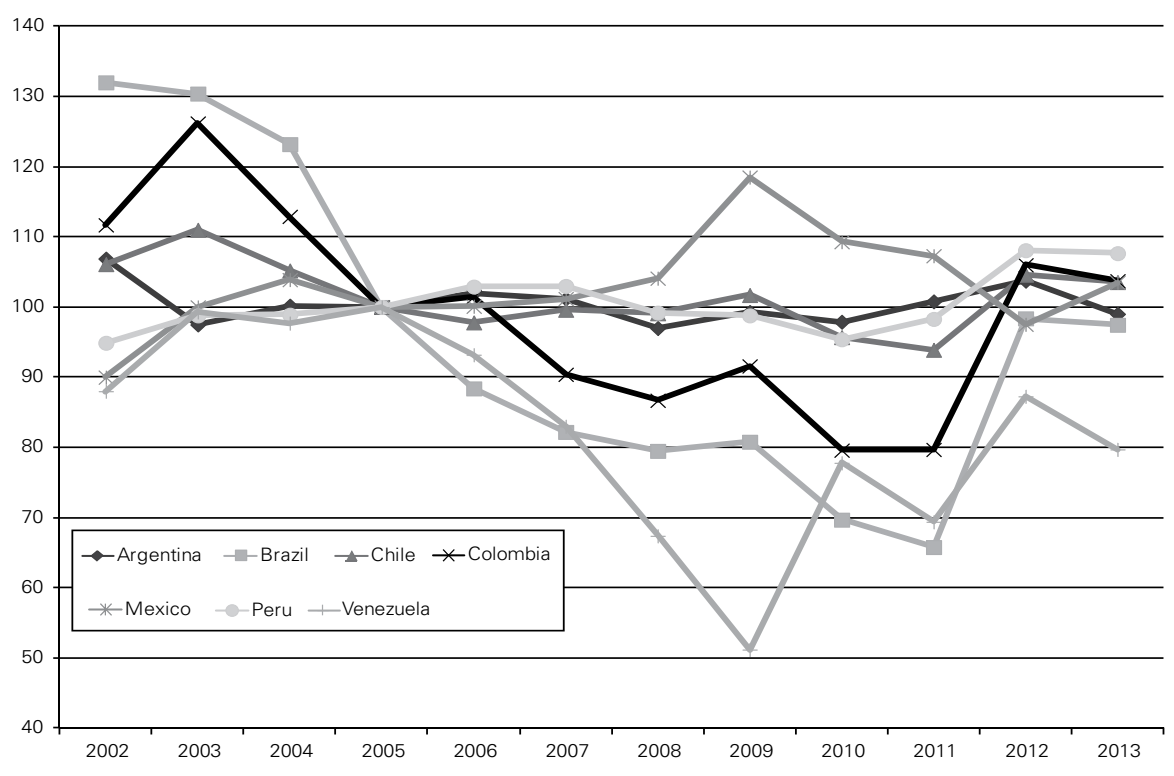

Source: ECLAC - Data Bases and Statistical Publications.

Note: Annual averages. A country's overall real effective exchange rate index is calculated by weighting its real bilateral exchange rate indices with each of its trading partners by each partner's share in the country's total trade flows in terms of exports and imports. A currency depreciates in real effective terms when this index rises and appreciates when it falls.

In the post-global financial crisis context, CAR was also predominantly endogenous in Brazil. After implementing some slight capital controls in 2009 and 2010, it was only after January 2011 (when the first prudential financial regulation tool was implemented) and, mainly, after July 2011 (when the Brazilian government adopted a broader regulation of the FX derivatives operations) a more comprehensive regulation has been launched, encompassing both CAR (capital controls and prudential financial regulation) and FX derivatives market regulation (FXDR). This new regulatory approach was an integral part of a broader change in the conduction of economic policy during the first Dilma Roussef's government (2011-2014). On the one hand, $\mathrm{BCB}$ adopted a more flexible monetary policy with the use of broader tools of monetary policy, including macro-prudential measures, and since August 2011 began a gradual and continuous reduction in the interest rates (from 12.5\% in August 2011 to $8.5 \%$ in June 2012) so adopting a more "forward looking" behavior. The BCB policy changed by mid-2013, when the policy rate (Selic) target began to increase again in order to face inflationary pressures. 
With the adoption of CAR and FXDR over 2010-2012, the Brazilian government increased its policy space and was able to manage the level of the exchange rate, curbing the currency appreciation trend caused by huge capital flows and derivatives carry trade, as we will analyze in the next section.

\section{CAPITAL ACCOUNT REGULATION AND FX DERIVATIVES REGULATION}

Before detailing CAR and FXDR in Brazil after the global financial crisis, it is worth to clarify that this last type of regulation is key in Brazil due to the specificities of the FX derivatives market in Brazil which gave rise to a central role of this market in the trend of the country's exchange rate $(\mathrm{BRL})^{5}$. This central role stems from the much higher liquidity and depth of the FX futures market, in comparison with the FX spot market. The predominance of the organized segment in the FX derivatives markets (i.e., futures traded in BM\&F Bovespa) is a specificity of Brazil's currency market. According to Avdjiev et al. (2010), the BRL was the second most traded currency worldwide in the organized derivatives markets in 2010.

A major distinction of the Brazilian FX derivatives (futures and OTC) market is that these operations are non-deliverable. This means that gains or losses in these operations are liquidated in domestic (BRL - Brazilian real), and not in foreign currency (USD). Due to their non-deliverable legislation, the margin requirements of FX futures transactions can be fulfilled in BRL. Along with the unrestricted access of non-residents to the FX futures market in the context of financial liberalization, this specific norm has contributed to its higher liquidity in comparison with the FX spot market as FX futures operations can be carried out without any effective foreign currency flows.

Both before (2003 to mid-2008) and after (since 2009) the global financial crisis, during periods of low risk aversion, foreign institutional investors have become the most important investor group in the FX Futures market, fostering a real appreciation trend through derivative carry trade. This is a different kind of currency speculation strategy, compared to the canonical carry trade through spot market operations - when an investor borrows money in a currency with a low interest rate and uses it to take long positions in currencies backed by high interest rate (Gagnon and Chaboud, 2007). This strategy presents advantages because of their inherent high degree of leverage (as in order to be carried out, financial derivatives operations require only the payment of a margin requirement).

In derivatives markets carry trade expresses itself as a bet which results in a short position in the funding currency and a long position in the target currency

\footnotetext{
${ }^{5}$ Predominantly an appreciation trend, i.e., a fall of the BRL/USD exchange rate which is the price of USD
} 
(Idem, 2007). In the case of Brazil, due to the huge differential between the internal and external interest rates, since 2003 foreign investors have taken, predominantly, one way bets on the Brazilian currency appreciation through short positions in the FX futures market (selling USD dollars and buying BRL), which has resulted in downward pressure on the USD price and, thus, in upward pressure on the BRL price.

FX future and spot markets are linked by the arbitrage carried out mainly by banks as the dealers in the FX spot market. In front of the downward trend of the USD futures price, these agents took the contrary position of foreign investors in the FX futures market (long position in USD and short in BRL). With this strategy, banks have earned arbitrage profits and, at the same time, caused additional appreciation of the Brazilian currency.

The derivatives carry trade turns out to be even more attractive in Brazil due to the non-deliverable feature of the FX futures market. In the case of Brazil, until October 2010, foreign and domestic agents could engage in derivatives carry trade not even investing on the margin, as usual with derivatives operations, but without disbursing one USD. More than that, this carry trade strategy could also be performed without the expenditure of one single BRL because investors could meet their margin requirements in BRL via domestic borrowed securities or guarantees from local banks. Despite the leadership of foreign investors, profit-seeking domestic agents, such as institutional investors and companies, have also engaged in derivatives carry trade (Fritz and Prates, 2014).

Therefore, while other countries only face a problem of low efficacy of capital controls to deal with FX derivatives operations (due to its high degree of leverage), Brazilian authorities were dealing with an even greater challenge, as these operations could simulate the impact of capital flows on the exchange rate without any effective foreign currency flows. Consequently, capital controls, which focus only on foreign capital flows, have proven to be ineffective in restraining them. At the same time, prudential financial regulation was also insufficient as it reaches only financial institutions. Therefore, the two kind of CAR do not reach operations carried out by non-resident investors and non-financial resident agents in the FX future market ${ }^{6}$.

The Brazilian regulatory authorities after some time realized this constraint. Since October 2010, they have launched, along with CAR, specific measures to tap FX derivatives operations, the already mentioned "FX Derivatives Regulation" (FXDR). This new kind of regulation has revealed to be key in restraining the BRL appreciation trend and, in turn, mitigating the economic policy dilemma faced by the Brazilian government, mainly, containing inflationary pressures without reinforcing the exchange rate misalignment (Figure 6).

\footnotetext{
${ }^{6}$ For a detailed explanation of the differences among the three kinds of regulations, see Prates (2014).
} 


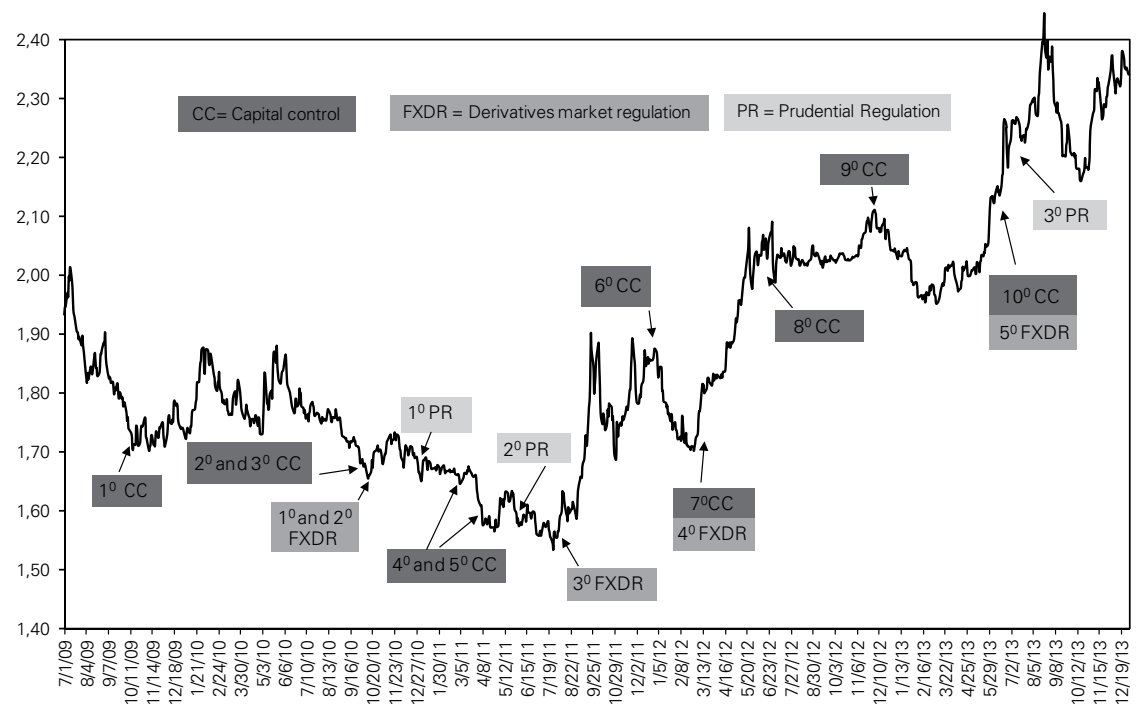

Source: Authors' elaboration with data from Central Bank of Brazil.

In October 2010, a price-based capital control (a financial tax on inflows, called Imposto de Operações Financeiras, IOF), already adopted at a low level in 2009 , was increased to curb the undesirable effects on financial and macroeconomic stability of one important kind of capital flows outside the scope of prudential financial regulation: portfolio investment in equity and fixed income. Brazilian government a few days later also closed a loophole that allowed foreign investors to avoid the higher tax on fixed income investments established before. Moreover, the first FXDR was implemented: the IOF on margin requirements on FX derivatives transactions was increased from 0.38 per cent to 6 per cent and some loopholes for IOF on margin requirements were closed (Table 1, in annex).

However, the first rounds of CAR and FXDR showed to be insufficient, as the IOF was too low to stem the derivatives carry trade due to its high leverage degree. Moreover, private agents found loopholes to circumvent the regulations (Figure 1). One of the main channels of circumvention after October 2010 was the increase in bank's short dollar positions in the spot currency market. In fact, the IOF on portfolio inflows encouraged the build-up of long real/short dollar positions in the on-shore derivatives market, that is, the derivatives carry trade supported by resident banks.

To close this loophole, the Central Bank of Brazil adopted a non-interest reserve requirement on these positions in January 2011, which is a prudential financial regulation tool. Nevertheless, banks found another channel of regulatory arbitrage by switching to short term foreign borrowings which also allow them to obtain arbitrage gains between the internal and external interest rates. The regulatory response was the IOF on this kind of capital flows adopted in March 2011. 
However, private agents were able to make longer term loans giving the excess of liquidity and searching for yield in the international financial market. Then, in April the government extended the IOF to these loans. Consequently, until the first semester of 2011, the impact of the CAR was mainly on the composition of inflows rather than on their volume.

Concerning the currency appreciation trend, this could be curbed only after the launch of a broader FXDR in the end of July 2011. At that time, the government imposed a financial tax of 1 per cent on excessive long positions on BRL in the FX derivatives market. These measures at least had a longer lasting effect as they reach not only the marginal requirements, but the notional value of the carry trade operations at the FX derivatives market. The exchange rate BRL/US\$ increased from 1.70 in $02 / 28 / 2012$ to 2.00 in 18/05/2012, a nominal devaluation of $17.6 \%$ (Figure 1 ).

An additional reason for such exchange rate behavior is some reduction in the net capital flows to Brazil since mid-2011 due to both the BCB policy determination to reduce short-term interest rate and the increase of risk aversion of foreign investors due to the higher likelihood of the imminence of a euro crisis. Therefore, besides shaping the composition of capital flows, the CAR launched by Brazil began to affect the size of flows in the new internal and external setting. This new setting, in turn, has allowed the loosening of capital controls since December 2012 (Table 1).

Yet, in the second quarter of 2013, it turned out that the effectiveness of CAR on capital inflows and FXDR on investors' long positions in FX derivatives depended on the phase of the capital flows cycle; in other words, this effectiveness was highly asymmetric in its boom and bust phases.

As mentioned in the Introduction, in May 2013, when Fed indicated that it might begin tapering its quantitative easing policy toward the end of the calendar year, global investors launched a portfolio adjustment that caused a temporary but significant reversal in capital flows to the US, putting upward pressures on the exchange rates of many emerging economies (BIS, 2014), the most vulnerable to global investor due to the monetary asymmetries of the international monetary system (see section 2.1).

The BRL was one of the most affected, mainly due to the higher liquidity and deepness of the Brazilian currency and financial markets and the huge net short positions of foreign investors in the FX future market - which bet on the BRL appreciation in that moment (Prates, 2014). In order to mitigate the currency depreciation, the government withdrew in June and July virtually all CAR and FXDR. Only the IOF for new and renewed foreign loans with maturities of up to 1 year remained in force (Table 1).

Then, in face of the cycle downturn, the regulations were counter-cyclically removed. However, the quick response of Brazilian policy makers was insufficient to curb the currency depreciation. In a setting of flight to quality (i.e, to U.S Treasury bonds) and high risk aversion, the removal of the broader regulatory framework which only penalizes bets in favor of the BRL was almost harmless to 
stem the currency depreciation. Its only impact was on the foreign portfolio investment in the public bonds market, which were stimulated by the greater returns after the IOF withdrew and the policy rate rise since March 2013 (Prates, 2014).

However, theses inflows were insufficient to stop the currency depreciation due to the very dynamic of the Brazilian currency market. As during the boom, in the bust phase changes in investors' positions in the FX derivatives market were the main determinant of the BRL trend. Indeed, the withdrawal of the IOF on long positions made easier the portfolio adjustment to short positions, which means bets on the BRL depreciation. In this setting, only a financial tax on excessive short positions (i.e, a FX derivatives regulation which penalize bets on the BRL depreciation) could restrain this process. Even if a capital outflow regulation were in force, although useful, it would be insufficient for the same reason (i.e., the currency market features).

\section{SOME LESSONS FROM THE BRAZILIAN EXPERIENCE}

Financial globalization has been featured by broader instability because both the higher frequency of currency crises and speculative attacks and the smaller domestic economic policy autonomy in this setting. Cyclical capital swings have strong effect on major macroeconomic variables, such as exchange rates, interest rates, domestic credit, and asset prices. In order to increase the room of maneuver of the exchange rate regime in emerging economies some measures to reduce the volatility of capital flows and the likelihood of speculative attacks on their currencies are necessary. As we have seen in this paper, one possibility to enhance the management of exchange rates in emerging economies is the use of CAR that includes capital controls and/or prudential financial regulations.

Concerned with that amount and volatility of capital flows to emerging economies after the contagious of the 2008 crisis, IMF revised its official position towards capital controls. By introducing the new term "capital flow management measures" (CFMs), the Fund gives more policy space to emerging economies subject to major capital inflow surges inasmuch it loosened the clear-cut hierarchy between instruments to manage capital flows which cover the whole range of macroeconomic policies, macroprudential measures (MPM) and capital controls. Yet, by labeling CFMs as a temporary instrument, the IMF still supports financial liberalization in these economies as a final goal, keeps discriminating between CFMs and MPMs and set bounds to emerging economies' policy space and their country-specific needs.

Concerning the Brazilian recent experience, some lessons can be learned in dealing with capital flows and agents FX positions:

(i) In countries with open, depth and non-deliverable FX derivatives markets, a third type of regulation, the FX derivatives regulation, needs to be adopted along with CAR (capital controls and prudential financial regulation). While other countries faced only a problem of low efficacy of these two regulations due to the high 
leverage degree of derivatives operations, in Brazil they turned out to be ineffective as these operations are liquidated in domestic currency. This means that they are likely to have an impact on the exchange rate with very low or even without any foreign capital inflows or outflows taking place. Besides that, most of these synthetic operations are carried out in the Brazilian futures exchange - the derivatives organized market - by a wider set of agents beyond non-financial institutions, such as resident companies and non-resident investors. Thus, neither prudential financial regulation measures nor capital controls are sufficient to curb these operations.

(ii) In Brazil, CAR and FXDR have had two goals: (a) a macroprudential one, namely, limiting the financial fragility associated with capital flow reversals and FX derivatives exposures; (b) increasing the policy space to control the key macroeconomic prices (exchange rate and interest rate). There are important feedbacks between these two goals: as the Brazilian experience before the global financial crisis showed, currency appreciation stimulates speculative positions in FX derivatives, threatening financial stability. Therefore, the capacity of maintaining the exchange rate in a competitive level (second goal) contributes to financial stability (first goal).

(iii) There are important feedbacks and complementarities among capital controls, prudential financial regulation and FXDR, as much as between these measures and macroeconomic policy Capital controls need to be adopted to cover particular types of capital flows that are outside the scope of prudential regulation (for instance, foreign loans by non-financial companies). Moreover, FXDR may be needed to curb currency appreciation and/or financial risks in emerging economies with open and sophisticated FX derivatives markets, depending on the institutional features of these markets (in Brazil, the non-deliverable feature of FX derivatives and the predominance of futures traded in BM\&F Bovespa). In turn, as Fritz and Prates (2014) highlighted, in the case of Korea the adoption of prudential financial regulation in the aftermath of the global financial crisis has been able to reach FX derivatives operations as they are carried on OTC markets where banks perform the role of counterparts in all transactions and are liquidated in US dollars. Thus prudential regulation has been able to cover all operations. Therefore, it is not possible to establish a hierarchy among instruments to manage capital flows and prevent their undesirable consequences, as supported by the current IMF approach.

(iv) A wider interest rate differential stimulates regulatory arbitrage, mainly in case of countries with sophisticated financial markets. In this context, CAR and FXDR have to be even more dynamic, flexible and adjustable, involving a steady "fine-tuning" to close loopholes found by private agents through spot and FX derivatives transactions. Only when Brazilian government adopted the three kinds of regulations simultaneously (capital controls, prudential financial regulation and FXDR), the policy effectiveness increased in terms of protecting the Brazilian currency from upward pressures.

(v) CAR and FXDR need to be a permanent, yet flexible part of the policy 
toolkit of emerging economies to increase their policy space and reduce the risks associated with liability structures towards capital flow reversals. Therefore, CAR and FXDR are integral part of the macroeconomic policy, as they can help economic authorities to face and eventually solve some macroeconomic trade-offs, as it is the case of a situation in which the central bank wants to intervene in the FX market in order to affect nominal exchange rate, and at the same time would like to avoid the fiscal costs to sterilize such operations.

\section{REFERENCES}

Andrade, R. and Prates, D.M. (2013). "Exchange rate dynamics in a peripheral monetary economy: A Keynesian perspective". Journal of Post-Keynesian Economics, 35(3): 399-416.

Arestis, P., Paula, L.F. and Ferrari-Filho, F. (2011). "Inflation targeting in Brazil”. International Review of Applied Economics, 25(2): 127-148.

Avdjiev, S., Upper, C. and von Kleist, K. (2010). "Highlights of international banking and financial market activity”. BIS Quarterly Review, December.

Baumann, B. A., and Gallagher, K.P. (2012). "Navigating capital flows in Brazil and Chile”. Initiative for Policy Dialogue Working Paper Series, June.

Biancareli, A. (2008). "A visão convencional sobre a abertura financeira e suas mutações recentes: uma resenha crítica”. Texto para Discussão IE/UNICAMP n. 143, June.

BIS (2014) BIS 84th Annual Report. Basel: Bank for International Settlements, June.

Cardoso, E. and Goldfajn, I. (1998). "Capital flows to Brazil: The endogeneity of capital controls". IMF Staff Papers 45(1): 161-202

Central Bank of Brazil (2014), http://www.bcb.gov.br, access in June 2014.

Chamon, M. and Garcia, M. (2016). “Capital controls in Brazil: Effective?” Journal of International Money and Finance 61: 163-187.

Dodd, R. and Griffith-Jones, S. (2007). Brazil's Derivatives Markets: Hedging, Central Bank Intervention and Regulation. Santiago: ECLAC.

Economic Commission for Latin America - ECLAC (2014), Data Bases and Statistical Publications, http://website.eclac.cl/infest/ajax/cepalstat.asp? carpeta=estadisticas\&idioma=i, access in July.

Eichengreen, B. (2004), Capital Flows and Crises. Cambridge: The MIT Press.

Epstein, G., Grabel, I. and Jomo, K.S. (2003). "Capital management techniques in developing countries”. Working Paper Series n ${ }^{\circ}$ 56, University of Massachusetts, April.

Fritz, B. and Prates, D.M. (2014). "The new IMF approach to capital account management and its blind spots: Lessons from Brazil and South Korea”. International Review of Applied Economics 28(2): 210-239.

Gagnon, J.E. and Chaboud, A.P. (2007). "What can the data tell us about carry trades in Japanese Yen?" International Finance Discussion Papers, No 899, Board of Governors of the Federal Reserve System, July.

Gallagher, K. (2012). The IMF's New View on Financial Globalization: A Critical Assessment, Pardee Center, Issues in Brief No. 2.

Gallagher, K., Griffith-Jones, S. and Ocampo, J.A. (2012). "Capital account regulations for stability and development: A new approach". In Regulating Global Capital Flows for Long-Run Development. Boston University/Pardee Centre Task Force Report, March.

Klein, M.W. (2012). “Capital controls: Gates versus walls”. NBER Working Paper No. 18526, November. 
Harvey, J.T. (2009) Currencies, Capital Flows and Crises: A Post Keynesian Analysis of Exchange Rate Determination. London: Routledge.

He, D. and McCauley, R. (2010). "Offshore markets for the domestic currency: monetary and financial stability issues”. BIS Working Papers no. 320. Basle: BIS, September.

IEDI (2012), "A maior eficácia dos controles sobre captações externas associada a taxa de juros baixos e câmbio estável”. Carta IEDI no. 547, November.

International Monetary Fund - IMF (2008). "Reaping the benefits of financial globalization". IMF Occasional Paper 264, December.

International Monetary Fund - IMF (2012). The Liberalization and Management of Capital Flows An Institutional View. Washington D.C: International Monetary Fund, November.

International Monetary Fund - IMF (2013). International Financial Statistics, http://elibrary-data.imf. org/finddatareports.aspx?d=33061\&e=169393, access in July 2014.

Kose, M., Prasad, E., Rogoff, K. and Wei, S-J. (2006). "Financial globalization: A reappraisal”. IMF Working Paper 06/189, August.

Magud, N. and Reinhart, C. (2006). "Capital controls: An evaluation”, NBER Working Paper $\mathrm{n}^{\circ}$ 11973, January.

Ostry, J., Ghosh, A., Habermeier, K., Chamon, M., Qureshi, M. and Reinhardt, D. (2010), “'Capital inflows: The role of controls". IMF Staff Position Note 10/04, February.

Ostry, J., Ghosh, A., Habermeier, K., Laeven, L., Chamon, M. Qureshi, M. and Kokenyne, A. (2011). “Managing capital inflows: What tools to use?” IMF Staff Discussion Note 11/06, April.

Paula, L.F. (2011). Financial Liberalization and Economic Performance: Brazil at Crossroads. London: Routledge.

Paula, L.F., Ferrari-Filho, F. and Gomes, A.M. (2013). "Capital flows, international imbalances and economic policies in Latin America”. In Arestis, P. and Sawyer, M. (ed.). Economic Policies, Governance and the New Economics. Basingstoke: Palgrave Macmillan.

Prates, D. M . (2014). "How to evaluate financial regulation of Brazil”. In: Bresser Pereira, L.C., Kregel, J. and Burlamaqui, L. (ed.). Financial Stability and Growth - Perspectives on Financial Regulation and New Developmentalism. London \& New York: Routledge.

Prates, D. M. (2015). A Gestão do Regime de Câmbio Flutuante no Brasil: Especificidades e Dilemas. Brasília: IPEA.

Prasad, E., Rogoff, K., Wei, S. and Kose, M. (2003). "Effects of financial globalization on developing countries: Some empirical evidence”. Mimeo. Washington D.C.: International Monetary Fund, March.

Schulmeister, S. (1988). "Currency speculation and dollar fluctuations". Banca Nazionale Del Lavoro Quarterly Review, 167: 343-365.

Stiglitz, J. (2000). “Capital market liberalization, economic growth, and instability”, World Development, 28(6): 1075-1086.

Tobin, J. (1978). “A proposal for international monetary reform”, Eastern Economic Journal, 4: 153-159. 


\section{ANNEX}

Table 1. Brazil: Capital account regulation (capital controls - CC and prudential financial regulation - PR) and FX derivatives regulation (FXDR) - 2009/2013

\begin{tabular}{|c|c|c|c|}
\hline Data & $\begin{array}{l}\text { Number } \\
\text { and Kind }\end{array}$ & Measure & Agents \\
\hline Oct./2009 & $10 \mathrm{CC}$ & $\begin{array}{l}\text { The Ministry of Finance implemented a } 2 \% \text { financial tran- } \\
\text { saction tax (IOF) on non-resident equity and fixed income } \\
\text { portfolio inflows. }\end{array}$ & $\begin{array}{l}\text { Non-resident } \\
\text { investors }\end{array}$ \\
\hline Oct./2010 & $\begin{array}{l}20 \text { and } \\
3 \text { CC }\end{array}$ & $\begin{array}{l}\text { (i) IOF increased from } 2 \text { to } 4 \text { percent for fixed income } \\
\text { portfolio investments and equity funds. } \\
\text { (ii) IOF increased to } 6 \text { percent for fixed income } \\
\text { investments } \\
\text { (iii) Limitations were also introduced on the ability of } \\
\text { foreign investors to shift investment from equity to fixed } \\
\text { income investment }\end{array}$ & $\begin{array}{l}\text { Non-resident } \\
\text { investors }\end{array}$ \\
\hline Oct./2010 & $\begin{array}{l}10 \text { and } 20 \\
\text { FXDR }\end{array}$ & $\begin{array}{l}\text { (i) IOF on margin requirements on FX derivatives transac- } \\
\text { tions increased from } 0.38 \text { percent to } 6 \text { per cent } \\
\text { (ii) Loopholes for IOF on margin requirements were } \\
\text { closed: foreign investors in the futures markets were } \\
\text { no longer allowed to meet their margin requirements } \\
\text { via locally borrowed securities or guarantees from local } \\
\text { banks, which allowed them to avoid payment of the tax }\end{array}$ & $\begin{array}{l}\text { Resident banks, } \\
\text { institutional } \\
\text { investors and } \\
\text { companies and } \\
\text { non-residents } \\
\text { investors }\end{array}$ \\
\hline Jan./2011 & $10 \mathrm{PR}$ & $\begin{array}{l}\text { Non-interest reserve requirement equivalent to } 60 \\
\text { percent of bank's short dollar positions in the FX spot } \\
\text { market that exceed US } \$ 3 \text { billion or their capital base, } \\
\text { whichever is smaller (to be implemented over } 90 \text { days) }\end{array}$ & Resident banks \\
\hline Mar./2011 & $40 \mathrm{CC}$ & $\begin{array}{l}\text { Increased to } 6 \text { percent the IOF on new foreign loans } \\
\text { (banking loans and securities issued abroad) with } \\
\text { maturities of up a year. Companies and banks previously } \\
\text { only paid a } 5.38 \text { percent IOF on loans up to } 90 \text { days. }\end{array}$ & $\begin{array}{l}\text { Resident banks } \\
\text { and companies }\end{array}$ \\
\hline April/2011 & $50 \mathrm{CC}$ & $\begin{array}{l}\text { (i) } 6 \text { percent IOF extended for the renewal of foreign } \\
\text { loans with maturities of up a year } \\
\text { (ii) } 6 \text { percent IOF extended for both new and renewed } \\
\text { foreign loans with maturities of up to } 2 \text { years }\end{array}$ & $\begin{array}{l}\text { Resident banks } \\
\text { and companies }\end{array}$ \\
\hline July/2011 & $20 P R$ & $\begin{array}{l}\text { The Non-interest reserve requirement became } \\
\text { mandatory for amounts over USD } 1 \text { billion or their capital } \\
\text { base (whichever is smaller). }\end{array}$ & Resident banks \\
\hline July/2011 & 30 FXDR & $\begin{array}{l}\text { Excessive long positions on } B R L \text { off all agents pay a } \\
\text { financial tax of } 1 \text { percent. This tax can be increased up to } \\
25 \text { per cent }\end{array}$ & $\begin{array}{l}\text { Resident banks, } \\
\text { institutional } \\
\text { investors and } \\
\text { companies and } \\
\text { non-residents } \\
\text { investors }\end{array}$ \\
\hline Dec/2011 & $60 \mathrm{CC}$ & $\begin{array}{l}\text { IOF on equity and fixed income (linked with } \\
\text { infrastructure projects) portfolio inflows reduced to } 0 \% \text {. }\end{array}$ & $\begin{array}{l}\text { Non-resident } \\
\text { investors }\end{array}$ \\
\hline
\end{tabular}




\begin{tabular}{|c|c|c|c|}
\hline Mar./2012 & $70 \mathrm{CC}$ & $\begin{array}{l}\text { (i) } 6 \text { percent IOF extended for both new and renewed } \\
\text { foreign loans with maturities of up to } 3 \text { years } \\
\text { (ii) Export advanced payment transactions with maturities } \\
\text { of more than a year prohibited } \\
\text { (iii) } 6 \text { percent IOF extended for both new and renewed } \\
\text { foreign loans with maturities of up to } 5 \text { years }\end{array}$ & $\begin{array}{l}\text { Resident banks } \\
\text { and companies }\end{array}$ \\
\hline Mar./2012 & 40 FXDR & $\begin{array}{l}\text { Exporters hedge operations (up to } 1,2 \text { times the exports } \\
\text { of the previous year) exempted from the IOF. }\end{array}$ & $\begin{array}{l}\text { Resident expor- } \\
\text { ters }\end{array}$ \\
\hline June/2012 & $80 \mathrm{CC}$ & $\begin{array}{l}6 \text { percent IOF only for new and renewed foreign loans } \\
\text { with maturities of up to } 2 \text { years (namely, the changes } \\
\text { adopted in March were reversed) }\end{array}$ & $\begin{array}{l}\text { Resident banks } \\
\text { and companies }\end{array}$ \\
\hline Dec./2012 & $90 \mathrm{CC}$ & $\begin{array}{l}\text { (i) } 6 \text { percent IOF for foreign loans with maturities of up } \\
\text { to } 1 \text { year } \\
\text { (ii) Export advanced payment transactions maturity } \\
\text { extended from } 1 \text { for } 5 \text { years. }\end{array}$ & $\begin{array}{l}\text { Resident banks } \\
\text { and companies }\end{array}$ \\
\hline Jun./2013 & $100 \mathrm{CC}$ & $\begin{array}{l}\text { IOF on fixed income portfolio inflows reduced to } 0 \\
\text { percent. }\end{array}$ & $\begin{array}{l}\text { Non-resident } \\
\text { investors }\end{array}$ \\
\hline Jun./2013 & 50 FXDR & $\begin{array}{l}\text { IOF of } 1 \text { percent on excessive long net positions of FX } \\
\text { derivatives of all agents reduced to } 0 \text { percent. }\end{array}$ & $\begin{array}{l}\text { Resident banks, } \\
\text { institutional } \\
\text { investors and } \\
\text { companies and } \\
\text { non-residents } \\
\text { investors }\end{array}$ \\
\hline Jul./2013 & $30 \mathrm{PR}$ & $\begin{array}{l}\text { Non-interest reserve requirement on bank's short dollar } \\
\text { positions in the FX spot market reduced from } 60 \text { percent } \\
\text { to } 0 \text { percent }\end{array}$ & Resident banks \\
\hline
\end{tabular}

Source: Authors' elaboration based on Central Bank of Brazil's and Minister of Finance's websites. 